\title{
Public-private or private-private energy partnerships? Toward good energy governance in regional and local green gas projects
}

Michiel A Heldeweg ${ }^{1 *}$, Maurits Sanders ${ }^{2,3}$ and Marc Harmsen ${ }^{4}$

\begin{abstract}
Background: An important avenue toward a proper 'energy transition' through regional and local projects is for government to collaborate with private sector organizations. In the energy sector, these latter organizations are often already involved in private-private partnerships for collaboration toward energy transition. This article focuses on the energy governance question whether in fact some of these forms of collaboration actually are about public governance, as they effectively lean on government involvement. This seems to be the case in the construction of biogas infrastructures for the production and distribution of green gas. This contribution discusses, on the basis of the case 'Biogas grid Noordoost Fryslân', if such collaboration should in fact be labeled as public-private partnership (PPP). In the energy governance discourse, this issue is important because in the organization of PPP, the public interest of energy transition comes with specific normative safeguards, originating in public law.

Methods: This article provides a legal normative assessment on the basis of a specific case, the Biogas grid Noordoost Fryslân. The relevant empirical data on this case is gathered by a document study, including research reports, policy plans, project documents, and by interviews. Experts from the Dutch energy sector were face-to-face interviewed by a semi-structured questionnaire. The analysis uses the concept of PPP in relation to public authority.

Results: On the basis of a confrontation between the results from literature and from the results of empirical case study of a biogas grid in the Dutch region Noordoost Fryslân, we conclude that governmental influence can take a 'disguised' form by 'quasi' private organizations, with major normative consequences for the mode of sustainable energy governance.

Conclusions: Administrative law in particular poses (binding) criteria for safeguarding public interests, such as on transparency, relevant also to the mode of governance applied in the promotion of renewable energy. Public standards for governance of renewable energy projects have to be sufficiently safeguarded, as regards their form and content of steering, while at the same time retaining the advantages, which ensue from private party involvement within PPP.
\end{abstract}

Keywords: Public-private partnerships (PPP); Energy transition and green gas

\section{Background}

\section{Green gas}

In $2020,16 \%$ of the national energy consumption in the Netherlands has to be from renewable resources [1]. In this respect, Dutch public officials have positive expectations about the developments of biogas in rural areas [2]. Biogas is produced out of biomass, for example,

\footnotetext{
* Correspondence: m.a.heldeweg@utwente.nl

${ }^{1}$ Department of Governance and Technology, The University of Twente, PO Box 2177500 AE, Enschede, The Netherlands

Full list of author information is available at the end of the article
}

from anaerobic manure digestion. In Dutch rural areas, many farmers and agricultural contractors have invested in co-digestion plants to generate energy from the anaerobic digestion of manure, by converting biogas in heat and electricity. Farmers can utilize this energy themselves, but from a societal perspective, it is far more attractive to upgrade the biogas to a higher heat content biomethane ( $85 \%$ to $90 \%$ methane), which can be injected into the natural gas grid [2]. In the Netherlands, this is known as 'green gas' [2]. As half of the Dutch energy consumption concerns natural gas (45 billion $\mathrm{Nm}^{3}$ per year), it is

\section{实 Springer}


believed possible to make a big, smart and sustainable energy transition step by exploiting the opportunities of regional production and distribution of green gas [3].

Biogas infrastructures in rural areas are essential to make large-scale production and distribution of green gas possible [4]. Such pipelines connect the co-digesters on the barnyards with a central place where the biogas is upgraded to the quality standards of natural gas and is injected in the regular gas infrastructure [2]. In many regions of the Netherlands, such as De Peel, Salland en Noordoost Fryslân, the possibilities of realizing a biogas grid are being explored.

\section{Challenges for energy governance}

Currently, there is no legal mandate for government to establish biogas grids - by itself or in collaboration with others. In practice, public and/or private sector organizations are interdependent if they want to get the complex undertaking of production and distribution of green gas going [5]. Collaboration between these types of organizations, however, does not develop spontaneously and has to be organized in mutually agreed partnerships. When collaboration and interdependence are a shared concern of public and private actors, we enter the discourse on public governance [6,7]. From this discourse, we know that public governance has moved beyond the image of government uni-centricly steering society as an 'unmoved mover', toward sharing responsibility in a multicentric and interactive way, across different polity layers and between various public and private actors [8-10]. The institutional design of PPPs clearly relates to this interactive scope [11] and is the focal point of this contribution, especially with respect to 'hidden ways' of government involvement and the subsequent need for public interest safeguards in partnership interaction with private parties on sustainable energy.

In the Dutch energy sector, there are forms of collaboration, which at first sight manifest as partnerships between private organizations only. These associations appear to be about merely private interests and about 'private-private partnership' as no government party seems to be involved at all. Upon closer inspection, however, these forms of seemingly mere private collaboration de facto also lean upon some disguised form of active public interest input as guided by government. Nevertheless, the set-up of such partnerships and the understanding that parties involved seem to have of the relevance of this public element in their collaboration do not display a concern for adherence to (norms originating in) public law - while the empirical fact of government guidance may be regarded as strongly indicative of such normative concerns. As a matter of, broadly speaking, legitimate governance, this factual state of affairs, understood as a particular type of collaboration, calls for a normative analysis of such governance concerns.

The focus is on examples of collaboration in unregulated, (more or less) experimental projects concerning the construction of regional biogas pipelines. These networks are planned to connect distributed biogas production to a central location, where the biogas will be upgraded to green gas and then injected into the natural gas grid [2]. The main organizations that are involved in such initiatives are (i) biogas producers, (ii) energy companies, and (iii) gas grid operators. All of these organizations are private law legal persons. However, it seems that in this type of collaboration, the gas grid operators are not involved on the basis of their privately defined societal interest, but rather on the basis of the public interest of the production and distribution of renewable energy, as - ultimately - defined by the central government. ${ }^{a}$ In this article, we present the view, on the basis of the regional case of Biogas grid Noordoost Fryslân, that because of such public orientation and of public influence, what appears as mere private collaboration and so as a mode of private energy governance (i.e., of private actors coordinating their actions regarding their interests in energy supply), should in fact be labeled as hybrid energy governance - of private and public actors coordinating their actions regarding energy supply thus including concern for public interests next to concern for private interests. If so, this collaboration amounts to PPP as hybrid governance, given the involved public interest in the energy transition as promoted authoritatively by one or more de facto public parties to the PPP, and so (norms originating in) public law may become relevant. This is important as a matter of energy governance because upon such a state of hybrid PPP affairs, the process of energy transition may also be guided (through the organization and operation of PPP's) by public norms and underlying public values and interests.

\section{Methods}

\section{Research methods}

In answering the research question, we analyze the term PPP against the backdrop of the key concept 'public authority'. The concept of public authority is of importance to the juridical qualification of (the functioning of) public sector organizations - as follows from the rule of law principle that public authorities '... must exercise powers conferred to them in good faith, fairly, for the purpose for which the powers were conferred, without exceeding the limits of such powers and not unreasonably' [12]. This legal analysis will be applied to the results of our own empirical case study. From December 2011 until February 2012, we studied the regional case of Biogas grid Noordoost Fryslân (in Dutch: Biogasleiding Noordoost Fryslân; henceforth BIONOF). The empirical data is gathered by a 
document study, including research reports, policy plans, and project documents and by studying recent publications and new items. Besides the document study, we gathered empirical data by (anonymous) interviews. We spoke with 14 key actors from the energy sector, including policy advisors, directors of energy companies, directors of gas grid operators, and business developers. These respondents were selected on the positive expectation that they were able to provide useful information about the nature and the way of the collaboration. A further six stakeholder-respondents were selected and interviewed on the basis of their functional involvement in the actual BIONOF project. They were face-to-face interviewed by a semi-structured questionnaire. The results of the interviews were included in interview reports, which were submitted for approval.

Upon combining the results from the study of relevant literature with results of empirical case study of BIONOF, we conclude that governmental influence can take a veiled form by 'quasi' private organizations involved in what looked to be mere private but in fact is hybrid collaboration. As a matter of good energy governance (i.e., coordination of action concerning energy supply that is, next to effective and efficient, legitimate), this calls upon all parties concerned to take into account the values and norms that are relevant to safeguarding public interests. Not only does this involve general public values, such as openness, transparency, certainty, integrity, and distributive justice and rule of law but also more specific energy supply-related values, such as accessibility, affordability, reliability, safety, and sustainability - the acknowledgement of which will depend on authoritative articulation within the given polity. Public values and norms are thus relevant also to the promotion of renewable energy and have to be complied with, while at the same time retaining the advantages, which ensue from the collaborative character of PPP. Good energy governance is a hybrid governance challenge.

In normative terms, the findings relate to BIONOF, but in a way that displays a general rule, that 'once the camel's nose gets inside the tent rapidly becomes uncomfortable', i.e., once government is involved, legal norms apply, originating in public law and impacting on the set-up of the PPP-arrangement at hand. This general rule also applies to all other instances of (regional or other) PPP where, similar to BIONOF, the 'legal fact' of government involvement is the case.

\section{An analytical framework for PPP}

The dominant view in the literature is that PPP is an ambiguous term signifying a so-called container concept [13], and some even speak of 'the PPP phenomenon' as 'an enigma' [14]. Given the multitude of interpretations of PPP, it makes little sense to here present the PPP definition. We have chosen for what we believe to be a minimal but robust definition, providing a description of no less and no more than the ontologically necessary and sufficient three basic elements (public, private, and partnership) in the most straightforward way and as such suitable to assess the nature of relevant existing actor partnerships in the Dutch energy sector [15].

Not every interaction between government and private actors can be regarded as PPP. PPP is a specific form of collaboration, in which government and private actors interact on an issue of public interest. As such, we take PPP as an institutionalized form of policy interaction, respectively an arrangement between (one or more) organizations from the public sector and (one or more) organizations from the private sector. This means we make a distinction between the characteristics of PPP and those of other, more noncommittal interactions between government and private actors. Three cumulative characteristics are especially important [15].

Firstly, the collaboration should be focused on the realization of public policy. Within the partnership, the public interest has to be represented authoritatively by, at least, one public actor [16]. It makes no difference whether the initiative to collaborate comes from a public actor or a private actor, as long as there is continuous involvement of government, which ensures the cooperative focus on attaining a public interest. The public actor in the PPP is (inescapably) embedded in public law, which adds to an adequate political legitimacy for the PPP as a whole [16].

Secondly, to actually achieve the policy goals, active involvement of private actors is necessary [16]. The aim of this involvement is to secure the input of resources by private organizations. They can contribute, for instance, by providing financial resources, technical expertise, or entrepreneurship or by enhancing social support. While government assumes dependency of public policy success on private actor participation, private actors consider their contribution to reaching policy goals to be beneficial in achieving their own goals, such as making profit. So, there is a jointly and mutually actively supported strategy that reflects a convergence of underlying interests [16].

Thirdly, PPP is an institutional arrangement of policy interaction. This means that there is a legally structured partnership between government and private actors [4]. This criterion excludes nonreciprocal, mere incidental, and noncommittal interactions between government and private actors. Interaction should involve action that is legally speaking from one entity - both 'internally', on the basis on agreed internal decision-making rules, and 'externally', as regards relations to third parties. Examples of legal structures that imply mutual obligations are 
framework-contracts, concessions, shares in joint companies, and participation in public bodies. Each legal structure provides a structural organizational context in which a partnership can develop [16].

The characteristics above can be brought together in the following definition of PPP:

PPP is a legally structured partnership between one or more public authorities and one or more legal entities under private law that focuses on the development and implementation of a joint strategy for the execution of a policy project [11].

This definition points our attention to the fact that under PPP, governance of public interests takes place in a partnership that comes with mutual and reciprocal obligations of the parties involved. From the outset, the partnership dictates a specific format for the determination and/or implementation of involved public and private interests as pursued by the public and private partners. Considered from a private law perspective, such a form of consensual self-regulation is a well-established practice - contracts are everywhere and they deal with all kinds of subjects. From a public law perspective, however, to ensure legitimacy in the pursuit of public interests by contract only is problematic especially because while contracts 'include' parties (as a legal regime inter partes), they also 'exclude' others (as a matter of privity of contract), whom are thus without 'voice' and vulnerable to seeing their interests harmed consequential to the PPP (such as a conventional manure treatment company that may lose out on resource once farmers sign onto a biogas grid). Given our definition of PPP, we need to consider if, also considering the specific institutional environment in which such PPP is applied, this type of collaboration is legitimate from a public values and norms perspective. We consider such legitimacy to be one of the building blocks to good energy governance in the form of public-private collaboration - aside from other forms (e.g., public service, public ownership, and regulation).

\section{Results}

Our findings firstly relate of the why and how of gas grids such as that of BIONOF. Next, we present our first analysis of whether the BIONOF project is in fact an instance of PPP. This then leads to a second, more focused analysis on the issue of authoritative public representation within PPPs (especially that of the BIONOF-type). Finally, we outline our findings as regards the basic system concerning the applicability of (norms originating in) public law to actors with a private legal form.

\section{Biogas grid Noordoost Fryslân}

Noordoost Fryslân is a sparsely populated area in the north of the Netherlands, which currently faces concern over its agricultural sector [17].
More generally, the Dutch agricultural sector is confronted with a policy dilemma between the importance of a profitable farming business and the importance of preventing an excessive environmental burden to the rural environment. The latter is due to the increased productivity of farms, engaging in global market competition [18] meanwhile causing considerable adverse environmental effects, such as soil acidification [19]. In recent years, farmers and interest groups are looking into emission-neutral business operations, to be achieved ultimately in 2030 [20]. This ambition is also supported by local governments and has become part of their public policies including that of the province of Fryslân, also as regards the development of the northeast region of Fryslân [17], such as by the initiative to converting biomass in biogas for the production and distribution of green gas, for which a biogas grid called the BIONOF grid, must be established.

Converting biogas to green gas is a new link in the energy supply from the gas production chain. For the BIONOF-project, this production chain has the following links: (i) purchasing, (ii) cleaning, (iii) transporting, and (iv) upgrading and delivering [21]. The green gas production chain starts with the purchase of biogas by the operator of the pipeline. This means that biogas production is not included in BIONOF. The co-digestion plants should be understood as autonomous units. One of the principles of the project is that the biogas producers are responsible for the functioning and operation of the plant in the yard. Once the operator has become the owner of the biogas, the cleaning process starts. This is done by removing, inter alia, $\mathrm{CO}_{2}$. Then, the compressed biogas is injected into the pipeline and transported to a central location [21]. There, the biogas is upgraded to green gas and then injected into the natural gas grid. From the natural gas grid, the energy resource will be delivered as green gas to the end-users. The 32$\mathrm{km}$ biogas pipeline has a capacity of $10,000 \mathrm{~m}^{3}$ green gas per hour [21]. The grid design has been completed, and construction will begin once the subsidy for construction is granted by the state [21].

Various parties are involved in the BIONOF project. Their involvement is organized in two chains. The 'primary chain' in BIONOF consists of the parties that are of vital importance to the technical realization of production and delivery of green gas. Farmers and farming companies ('producers'), energy supply companies, and grid operators are members of this primary chain.

The 'secondary chain' in BIONOF consists of parties that (merely) support the green gas project and have committed to its realization. A large private engineering consultancy firm, the province of Fryslân, the municipality of Leeuwarden (i.e., the provincial capital of Fryslân), the 'Gas Unie' (i.e., the leading Dutch producer of natural gas), and 
'Energy Valley' (i.e., a regional network organization of stakeholders - for-profit and not-for-profit stakeholders) are members of this chain.

It is important to know that, following changes in Dutch energy law (in 2006), production and supply of energy (especially gas and electricity) have been separated from energy transport - mainly to safeguard grid reliability $[22]^{\mathrm{b}}$ whereas energy companies used to combine these functions; since 2011, production and supply companies operate independently from companies involved in transport. According to current Dutch statutes on gas and electricity supply, the grid operators are responsible for the construction, management, and maintenance of public energy grids. However, as we shall see later, there is a legal difference in the position of grid operators as regards their regulated tasks concerning the public energy grids and their possible tasks (or involvement) in unregulated private of public-private grids, such as the BIONOF grid.

\section{First analysis - PPP or not?}

To determine the relevance of public law norms as criteria of good energy governance through the BIONOF type of collaborative action, we need to analyze if and how the public interest in sustainable energy (projects) influences decision-making in the aforementioned two chains. As far as the secondary chain is involved, clearly there is a public interest at stake because public parties have engaged in support of activities in the primary chain. When we look at the primary chain, the picture is less clear. Given that all concerned parties are private law legal persons, perhaps the conclusion would have to be that this is a chain of private-private partnership and therefore no public interest is involved other than that this arrangement for private-private interaction has support from a chain that also builds upon public interest. In terms of good energy governance, especially considering that public law norms are activated when public interests are at stake, we need to determine more accurately the nature of collaboration in both BIONOF chains - each on its own and both together.

As mentioned above, we listed the three conditions of our working definition of PPP: 1 . focus on realization of public policy, represented by at least one public party; 2 . active involvement (by securing resources) of at least one private party; 3 . an institutional arrangement in the form of a legally structured partnership. As a first step, we should look at these conditions more closely in respect of the primary and secondary chains in our BIONOF case.

\section{Focus on realization of public policy, authoritatively represented by at least one public party}

In general terms, of the case as a project, the three basic public energy interests to be considered are affordability, reliability, and sustainability [23]. Although private parties initiated the BIONOF project, clearly it touches on these public values and as such public involvement, if only through the secondary chain, makes good sense.

In the secondary chain, the public policy angle has indeed come with involvement by public parties - i.e., a municipality and the province. As such, the first condition of PPP is met.

With respect to the primary chain, this is a more difficult issue. None of the parties has a public character to the extent of being endowed with public legal powers. In such a quality, parties would be able to unilaterally and bindingly determine the legal position of others and thus actively and coercively pursue the public energy interest. Then again, there may be other shades of public that display less of a command and control (i.e., 'government') approach to policy-making, but more one of cooperating with and convincing of others (i.e., 'network governance'), but still with 'public law significance'. The latter significance would be at stake when certain parties (attempt to) influence private party behavior, by a claim to 'public voice' (i.e., to speak on behalf of the public interest), doing so by use of 'public means' (e.g. information, knowledge, time, workforce, capital, office space) and with possible 'public effects' (i.e., on others in their private interests and/or on the public at large in terms of the interest served). If such public law significance is the case and if at least one party can claim to authoritatively represent this public (energy) interest, then we could consider its collaboration with private parties as PPP and if and how it may be affected by (norms originating in) public law. Before actually presenting a more indepth analysis on public law significance, we should, however, first establish that at least the second and third PPP conditions are met (while assuming that the first condition is met both as regards the primary and the secondary chain) - or else there would be no relevant partnership to discuss.

\section{Active involvement (by securing resources) of at least one private party}

In general terms - of the case as a project - it was clear from interviews that most of the private parties involved are 'in it' for their private profit. At the same time, their involvement is vital to bringing together the necessary finances, technical expertise, entrepreneurship, and commitment (if only to provide the prime resource: manure). The interviews also revealed that the private parties involved consider the project to be relevant to achieving the public interest of enhancing the use of green gas and that they consider this interest to be in alignment with their own private interest.

As such, we may conclude that both in the primary and in the secondary chains, there is clear and active 
involvement of private parties to a project with public interest objectives, so that the second condition to PPP is also met.

\section{An institutional arrangement in the form of a legally structured partnership}

In general terms, of the case as a project, it is clear that the dual arrangement of two chains builds on two complementary but - legally speaking - rather different relationships. We need to determine their nature as this third condition is about separating informal, noncommittal, and discrete interactions from true partnerships.

As regards the secondary chain, the legal structure is that of a declaration of intent ('Intentieverklaring') between the parties named in the above (signed on $5 \mathrm{Feb}-$ ruary 2010) $[24]^{\mathrm{c}}$. Such a declaration clearly falls within the realm of so-called covenants or gentlemen's agreements. These are pseudo-contractual agreements that, at least in the Netherlands, became popular since the 1960s of the twentieth century and were meant to tie together strategic and sometimes also operational behavior of both public and private parties, by mutual agreement [25]. It was believed that cooperation could in some cases yield better policy results than achievable through 'command and control'. The lack of legal enforceability, given that these agreements generally were rather more about 'making an effort' than promising specific results, was (supposedly) substituted for the expectation that mutually agreed obligations would, as a matter of self-or coregulation, bring a greater willingness to reach mutually agreed objectives (or upon default, suffer the consequence of 'naming and shaming', or 'ostracism'). According to our research, the members of the secondary chain clearly had no intent of any 'meeting in court' upon default by any of the participants. This already begs the question if the secondary chain can, upon reflection, qualify as a PPP. In legal terms, the third condition seems questionable as it is, at its most, rather of a 'soft law' nature. We will not pursue a definite answer on this issue, but believe that given the 'network characteristics' of the second chain (being mainly about strategic coordination, in support of the primary chain), and the influence that it has upon factual commitment, that a declaration of intent can be regarded as a type of 'legally structured relationship' and so we can qualify the secondary chain as a PPP.

As to the primary chain, this displays the characteristics of a 'business deal', if only given that the parties involved have a profit interest and/or are investing resources in establishing the green gas grid. From the interviews, it became clear that as soon as the biogas grid is operational, the parties involved will sign private law contracts and juridical persons will be established. Contracts will be signed, on one hand, between the energy supply companies and the biogas producers, between the energy supply companies and the grid operators and on the other hand, between the two involved grid operators. In the latter contract, both involved grid operators will act as one legal entity as they will form one company that handles the exploitation of this particular biogas grid. Prior to these 'hard' legal arrangements, so prior to the grid being operational, all concerned parties have signed a memorandum of understanding, to the effect of making efforts to establish the grid and including the formats of the aforementioned contracts. From this state of affairs, we can deduce, that prior to the start of operations, the legal structure of the partnership is more of a soft law character (with limited legal significance) but upon the start of operating the grid, there is a clear hard law business deal in the form of legally binding contracts and a specific juridical person on the side of the involved grid operators - clearly meeting the third condition of being a PPP, clearly expressing legal implications with a bearing on the involved participants, with possible external effects on others.

\section{Second analysis - authoritative representation of the public energy interest}

Our concern for good energy governance is focused on the possible need to safeguard public (law) values and norms behind the public energy interest in green gas projects. Consequently, we need to determine if the BIONOF type of collaboration does, in its primary chain, qualify as PPP, especially if the first condition of PPP (i.e., 'publicness') is being met, as a matter of authoritative representation of the public energy interest by one or more parties involved.

Given that the private interest parties in the primary chain are clear (i.e., the farmers, the energy supply company), our focus of attention as to the 'authoritative public voice' in this chain is on the grid operators (Enexis and Stedin). They both are private law legal persons, but perhaps there is more of a public interest involved than meets the eye.

How do we determine the existence of an 'authoritative public (energy) interest representation'? Our perspective follows the approach of the Dutch Scientific Council for Government Policy [26]. A public interest is a societal interest, relevant to society as a whole - not merely to some individual(s) - for which government takes on the (final) responsibility, executed on the basis of public policy objectives, in the conviction that it can only thus be served properly (as this may not be expected spontaneously from markets or civil society).

Consequently, we need to look for government (in PPP) if we want to determine if indeed the public interest is authoritatively represented. Unfortunately, the definition of government is by no means settled. We have chosen to use the legal concept of 'public authority' as a point of 
reference, as this provides a conceptualization of government both in terms of function (of various types of organizations acting in service of public interests) and of norm applicability (of general public law, such as human rights and principles of proper administration).

The legal definition of 'pure public authority' points at the existence of a 'public legal mandate' as a conjunction of: ${ }^{\mathrm{d}}$

1. Statutory power - as an exclusive legal power, not available to all (as opposed to the power to contract), to unilaterally perform legal acts with general bindingness. This highest form of legislative power is generally reserved for public legal persons, such as state bodies (e.g., parliament, departments), provinces, and municipalities. This is not to say that these (or others) pure public authorities can only perform public law acts. They too need to acquire facilities (i.e., utensils - e.g., computers, office space), for which they need to also perform private law acts.

2. Public scope - to fulfill a government function, with a general scope (not just a specific private group) and on the basis of public funding, with assumed service to the public interest only.

In liberal democracies, actions by pure public authorities are legitimate only if underpinned by democratic consent and exercised under the rule of law. Hence, general norms of public law (such as those mentioned in the above - under 'Research methods' - e.g., good faith and reasonableness) automatically apply to all pure public authorities and do so in all their activities [27]. This stands to reason as the raison d'être of pure public authorities is in their legislative function, so they intrinsically belong in the ambit of public law.

The assessment of whether a public interest is represented in PPP should not be limited to whether a legal body with pure public authority is party to a PPP. Various legal systems, such as the UK and the Netherlands, also consider private law bodies without statutory powers but with public function to have public authority - as functional public authorities.

Broadly speaking, we may distinguish between two main groups:

1. Public or private legal persons (without statutory, but) with delegated legislative or conferred administrative legal powers (e.g., to grant subsidies or allowances, apply sanctions, or issue permits) again exclusively allocated to them, and of a unilateral nature.

2. Public or private legal persons without any legislative or administrative powers, but with a significant public function, following from two possible underpinnings: a. A public law legislative mandate to fulfill a particular public task (by performing private law legal acts or factual and informational activities). This may apply to both public and private legal persons - the task of grid operators concerning public electricity or natural gas grids, may typically be an example (when there is a legislative mandate), regardless of whether the grid operator is a public or private law body.

b. Only as regards private law organizations, outside legislative mandate (2a), various factors may point at a public function [27]. Ultimately, these need to 'provide proof' of an exclusive public interest task performed within arms' length of a public authority of the abovementioned kinds (i.e., pure or 2afunctional). Within arms' length expresses that there is a controlling, underlying public authority, by virtue of ownership (shares), right of appointment of governors, substantive $(50+\%)$ funding, binding policy guidelines, and/or ex ante supervision - as opposed to a private organization being positioned independently, at arms' length; outside of government control. These ('within') control mechanisms need to (in conjunction) be sufficiently strong to secure that the public interest scope, as (broadly) understood by the underlying public authority, is the leading objective in the operational actions of the private body. In effect, control as dominant empowerment and a strategic veto power; with the capacity to bindingly influence all operations - and as such moving beyond of what, for instance, a regulator of competition oversight would do. 'Exclusiveness' of the public interest task is to say that serving this interest is not merely a by-product of private interest or for-profit activities, but is the leading objective. Exclusiveness, generally, also expresses a monopoly position in the performance of public interest activities, in that these are dedicated specifically to service the public interest - not to private interests or merely consequentially. A private functional public authority that provides grants for sustainable energy projects may stand aside private banks or private funds (acting on commercial or social incentives) that offer similar services, but are not (necessarily and certainly not formally) guided solely by the public interest as viewed by the relevant underlying public authority. Following this criterion, private energy supply firms, commercially operating on the Dutch liberalized energy market, do not have functional public authority, but as regards private grid operators in as much as involved in nonpublic grids such as BIONOF, much will depend on whether they operate with a public interest scope as determined by 
an underlying public authority - as regards their status vis-a-vis public grid, their status as functional public authority followed from $2 \mathrm{a}$.

Because they lack public law legal powers, private bodies are unable to unilaterally determine citizens' freedoms (and which would make them pure public authorities or functional public authorities of the first kind), but they can use private law powers (of contract and property) to allocate funds (such as through private loans, donations, or allowances), deliver services, perform technical services and works, and provide information. If and when this is done within arms' length of an underlying pure public authority, this expresses a public interest significance, as this involvement then effectively comes with a dominant public voice in how the private body is to perform its tasks. One could argue that when public ties are indeed that strong, this second type of functional public authority is about the exercise of 'quasi-public law (legal) powers'. To establish such private bodies as public authorities may have diverse reasons, such as of placing a task-organization outside of immediate political control (and weighing of interests), of internal efficiency, or of increasing the likelihood of attracting outside private capital - quite aside from the fact that reasons may be a temporary matter, following privatization, while moving from a monopoly position toward being a competitor on a liberalized market (as many energy supply companies have done).

The below (Table 1) summarizes the (sub)types of functional public authorities:

Functional public authorities (of both subcategories 1 and 2) are also assumed to automatically be obligated to comply with all general norms of public law, but 'only when discharging a public function' [27] - compare, for example, the systematics of Article 6(5) Human Rights Act 1998 [28] and Article 1:1, section 1, under b of the Dutch General Administrative Law Act [29] This latter limitation (only with a public function) is especially relevant to the position of private law legal persons, as these may have a hybrid character, and so also perform activities outside the public interest realm. In such a case, the hybridity of these bodies does not refer to their legal form (i.e. a private legal person with a public authority status), but to their involvement in competitive market

\section{Table 1 Types of functional public authorities}

\begin{tabular}{|c|c|c|}
\hline \multicolumn{3}{|c|}{$\begin{array}{l}\text { Functional public authorities: public or private law bodies } \\
\text { (both in categories } 1 \text { and } 2 \text { ) }\end{array}$} \\
\hline \multirow{2}{*}{$\begin{array}{l}\text { 1. With non- } \\
\text { statutory public } \\
\text { powers (lower } \\
\text { legislative or } \\
\text { administrative) - } \\
\text { unilateral }\end{array}$} & \multicolumn{2}{|c|}{ 2. Without public law powers but } \\
\hline & $\begin{array}{l}\text { a. With legislative } \\
\text { mandate (public or } \\
\text { private bodies) - unilateral }\end{array}$ & $\begin{array}{l}\text { b. Otherwise with } \\
\text { exclusive public interest } \\
\text { scope (only private body, } \\
\text { aside from 2a) }\end{array}$ \\
\hline
\end{tabular}

transactions. The situation of grid operators not only managing their (part of the) public grid, as regulated, but also providing commercial/private grid services to large companies is a clear example. Of course, in such arrangements, the obligation to adhere to general public law norms should be limited, so as not to interfere with commercial activities - generally as an impediment.

As said, functional public authorities may be hard to distinguish from private public service companies (e.g., energy supply companies) or voluntary NGOs (e.g., private green certification or standardization organizations), active only on markets or only in civil society networks respectively certainly when government holds shares in these private bodies (as often in the process of privatization and liberalization - merely to ensure that they are, commercially speaking, properly launched) or subsidizes their activities (as when government feels that an NGO adds to the public policy objectives - merely upon the NGO's free willingness to commit to this activity). Clearly, however, as these private legal persons have no (partial) functional public authority, given that ultimately they operate out of a private (commercial or societal) interest - even if their activities (temporarily) align fully with public interest needs and so they are not automatically bound by general public law rules.

\section{Applicability of (norms originating in) public law}

Our analysis has already revealed that public authorities, pure and quasi/functional, automatically fall within the public law scope, and consequently, their organization and actions need to be in keeping with public law norms a normative state of affairs that may be recognized merely as a matter of unwritten law, but which is sometimes also explicitly prescribed by statute. This state of normative affairs does, however, not exclude the possibility, that (some) general public law norms are expressly (i.e., as opposed to automatically) made applicable to private bodies without (any kind of) public authority, as from a public interest viewpoint, their activities are considered too important and/or the market or network in which they function too vulnerable to perverse incentives. Although as private actors, they are 'naturally' entitled to a broad range of discretion in their actions, this range is expressly limited to avoid failure from the perspective of their actions (potential) public interest contribution. Roughly speaking, there are two ways by which any such express applicability of norms of (or originating in) public law can be arranged:

a. Public legislation or regulation - by general rules prescribing adherence to certain public law norms, often either (1) in an act on particular types of service organizations (e.g., societal enterprises) or (2) in an act that regulates transactions within a particular market (e.g., 
electricity or gas markets) or within certain networks of civil society (e.g., voluntary welfare/ care or cultural organizations and their clients or target groups).

b. Mandatory public instructions - by order of an underlying public authority, such as (1) conditions in an administrative act that provides financial means (e.g., a subsidy scheme) or (2) in a legal agreement (e.g., contracts, covenants) with an underlying principal body with public authority. Aside from these legal arrangements, which follow from a public interest perspective (that builds on government concern), there is yet a third express arrangement of

c. Private or self-regulation - by private law legal persons which, merely by themselves or together with others, commit to inter alia public law norms, such as under a good governance code (often under a 'comply or explain' regime).

So, altogether, there are three (a, b, and c) kinds of express public law arrangements that may compel not only adherence to general public law norms (e.g., equality and fair play) but also adherence to specific public law norms, relevant to a particular area of service (e.g., reliability of energy supply). The third type of (private) arrangement is the 'softest' form of engagement to public norms, as it is merely a private law arrangement (guided by private, commercial or societal, interests, or concerns) - if indeed any legal bindingness is involved. In the second type of arrangement, the contractual instruction has a limited value in the sense that the privity of contract rules out the possibility of third party protection - unless explicitly arranged.

In all three cases, applicability of public law norms does not make the private norm - subjects public parties - let alone parties with public authority. Essentially, they are only as a matter of their own private choice, involved in societal interests that coincide with a public interest (as defined by government). One can well imagine private enterprises and NGOs taking an interest in the promotion of sustainable energy - either as a market opportunity, as a matter of corporate social responsibility or as a core mission. This may even coincide and align perfectly with the public interest that government may have in sustainable energy. Crucially, however, these private initiatives are voluntary (and so may be abandoned freely) and they do not (nor can they claim to) authoritatively express the public interest, as the private actors may promote other alternatives than government would prefer. Hence, they do not, at least not automatically fall within the public law scope. Table 2 summarizes the various ranges and the applicability of public law:

\section{Discussion}

On the basis of the above analytical results, we conclude that within the primary chain of the regional case of BIONOF, only the grid operators are possible candidates for being the authoritative public interest authorities. Only they may qualify as functional public authorities, and so as government, whereas, for example, energy supply companies do not (authoritatively) represent the public interest, even though their function is vital to a properly working energy market. Whether grid operators in the BIONOF actually are functional public authorities is a matter we will now discuss.

Authoritative representation of the public energy interest As to the publicness of grid operators, the first thing to note is that the grid operators in BIONOF are private law legal persons, more in particular in the form of enterprises. They have a statutory task in the operations and maintenance of the gas transport grid, but not in

Table 2 Various ranges and the applicability of public law

\begin{tabular}{|c|c|c|c|c|}
\hline \multicolumn{5}{|c|}{ Applicability of public law: categorizing public authorities, firms, and NGOs } \\
\hline \multirow{2}{*}{$\begin{array}{l}\text { Actors } \rightarrow \\
\downarrow \text { Form and law }\end{array}$} & \multicolumn{3}{|l|}{ Public authorities } & \multirow{2}{*}{$\begin{array}{l}\text { Markets and civil societ) } \\
\text { Firms and NGOs }\end{array}$} \\
\hline & Pure & \multicolumn{2}{|l|}{ Quasi } & \\
\hline 1. Legal form & a. Public law body & \multicolumn{2}{|l|}{ b. Public or private law body } & $\begin{array}{l}\text { c. Private law body/ } \\
\text { natural persons }\end{array}$ \\
\hline \multirow[t]{3}{*}{ 2. Core determinant of form } & $\begin{array}{l}\text { a. Statutory power + exclusive } \\
\text { public scope }\end{array}$ & b. Other public law powers & c. (Not b and) & $\begin{array}{l}\text { d. Only private law powers } \\
\text { and interest scope }\end{array}$ \\
\hline & & & - Legislative mandate & $\begin{array}{l}\text { - On regulated market } \\
\text { (3c/4a to b) }\end{array}$ \\
\hline & & & $\begin{array}{l}\text { - Exclusive public } \\
\text { interest scope }\end{array}$ & $\begin{array}{l}\text { - On 'free' market } \\
\text { (but 4a to b) }\end{array}$ \\
\hline 3. Applicability general public law & a. Yes, automatically and fully & \multicolumn{2}{|c|}{$\begin{array}{l}\text { b. Yes, automatically but partially } \\
\text { (fully when public body) }\end{array}$} & $\begin{array}{l}\text { c. Only when specifically } \\
\text { arranged by } 4\end{array}$ \\
\hline \multirow[t]{3}{*}{ 4. Applicability of special public law } & \multicolumn{4}{|c|}{ Yes, if so arranged - in service of a specific public interest } \\
\hline & \multicolumn{4}{|c|}{ a. Public services (e.g., energy, education, care, transport) } \\
\hline & \multicolumn{4}{|c|}{ b. Public risks (e.g., environment, health, safety) } \\
\hline
\end{tabular}


respect of gas production grids such as the BIONOF grid (see Articles 1(1)(d-e) jo. 2(1) jo. 10 Natural Gas Act). Therefore, the statutory public safeguards apply to these private law grid operators only when exercising explicit public law tasks. The latter, however, is not the case in the field of sustainable energy projects since in these projects, grid operators have no regulated task. Such projects are as yet unregulated, so there is no statutory or regulatory underpinning that grid operators qualify as functional public authorities - contrary to what could be argued with respect to their position in operating the regulated main/public gas and electricity grids. In those cases, clearly one can well argue that by virtue of their legal task/ obligations, they do have functional/quasi public authority. We are, however, of the opinion that also with respect to unregulated regional projects such as that of BIONOF, grid operators may be considered to be positioned within arms' length of government and so be relevant, at least in their actions, to (norms originating in) public law. In this respect, two considerations are most relevant.

Firstly, but merely of an indicative nature, in 2011, the Dutch department for Economic Affairs officially stated that the increase of the share of energy generated regionally would call upon grid operators to make the necessary grid investments given their statutory task of safeguarding an efficient and reliable infrastructure [23]. In 2012, a legal provision was made in the Natural Gas Act to allow for 'sustainable decentralized experiments'. Implementation of the new Article 1(i) is, however, still awaiting the necessary ministerial decree to enter into force. Meanwhile, aside from these (future) statutory provisions, in the interviews, several respondents expressed the opinion that the central government will expect grid operators to make an effort to support the policy ambitions as regards climate and energy, such as by contributing to the development of biogas infrastructures. While such expectancy may not be irrelevant to actual behavior, it is a mere factual state of affairs that cannot by itself make (norms originating in) public law applicable.

Secondly, and crucially, the grid operators are owned by provinces and municipalities, who together hold all shares in them. From the interviews, it became clear that these public shareholders opt for active ownership (pursuing public policies through their ownership of shares), rather than passive, where ownership is merely a means to bringing a private enterprise in existence as a 'public-task agent' or safeguarding its existence (but not interfering in its activities) [30]. When active, clearly public authorities influence grid operators to pursue a public interest scope as the public owners see fit. Although the task is to-date unregulated, clearly in the BIONOF case, public ownership in Enexis and Stedin is instrumental to the objective of the energy transition and regarded as such by representatives of grid operators but also by other PPP participants.

\section{Good energy governance}

From this latter factual state of affairs, we conclude that grid operators can and, if so, should indeed be regarded as functional public authorities - even when operating in the realm of unregulated regional experiments with green gas, such as in BIONOF, because they authoritatively representing the public interest. Hence, we may indeed label regional collaboration of the BIONOF type: public-private partnership. Subsequently, the involved grid operators are functional public authorities and hence they are, regardless of the unregulated (regional) realm in which they operate, automatically obligated to adhere to general norms of public law. A normative state of affairs that may be termed a logical consequence of being an intrinsic part of a function which exclusively determines the scope of a particular public interest - i.e., energy supply. ${ }^{\mathrm{f}}$

Not only does this normative state of affairs influence the position of grid operators themselves but also it conditions the possible governance modes of regional cooperation with other parties, some of which are intrinsically private. The presence of a public party necessitates acceptance of principle of good public governance on the PPP collaboration, as only within the framework of a governancestructure that upholds principles or elements such as the rule of law, participation, responsiveness, consensus orientation, equity, effectiveness and efficiency, accountability, and transparency [31], collaboration between public and private parties can develop and yield acceptable results; without private interests pushing out public interests (or necessarily vice versa). Thus, the structure of regional collaboration has to secure a proper weighing not only of general public law values but also of specific public values relevant to the energy field, such as viability, safety, reliability, sustainability, and equal access - against the needs of positive private involvement (fitting with a liberalized energy market).

\section{Conclusions}

Where collaboration between public and private parties is used in an unregulated area as a means to make a much desired smart and sustainable energy transition in regions, applicability of public law values and norms nevertheless calls for critical reflection on how this collaboration takes shape, especially with a view on how public values and norms are properly safeguarded in a framework of good energy governance. This main conclusion follows from the results of our research, which is based upon a normative, legal analysis, given the type example of the BIONOF case. We believe this conclusion and the analysis upon which it is built was necessary as the empirical study of the BIONOF case revealed that respondents were unable to properly articulate the presumed grid operators' public interest responsibility. Thus, the challenge was to 
determine if such responsibility was, normatively speaking, the case and, if so, what its consequences would be in terms of normative requirements.

Applied to the BIONOF case, considered as a particular PPP type, we conclude that although grid operators are private entities and BIONOF is about an unregulated green gas experiment, grid operators are involved as quasi/functional public authorities, effectively representing the public interest as perceived - in more or less specific terms - by underlying (pure) public authorities. As such grid operators are automatically obligated to uphold norms of (or originating in) public law and PPP collaboration should, as a matter of hybrid good energy governance, reflect (also) these norms (as they present themselves in the given legal polity). In instances of local and regional transition to sustainable energy, private and public stakeholders should be well aware of the particular (hybrid) position that the grid operators' are in and the particular legal demands and responsibilities that rest upon them. In that sense, this contribution is about managing expectations and promoting accountability to the benefit of good (regional and local) energy governance. These conclusions call for a further analysis on how PPP relations in this type of collaboration should be organized to further proper safeguards for (organizational) adherence to such principles. ${ }^{\mathrm{g}}$

\section{Endnotes}

${ }^{a}$ The balance that gas grid operators must strike between private and public interests is the subject of a broader discussion - as observed, inter alia, by Steenhuijsen and De Bruijne in their study of the role of energy network companies in the energy transitions [32].

${ }^{\mathrm{b}}$ According to the Statute on independent grid management (Wet onafhankelijk netbeheer (Won) - entered into force in 2006), integrated energy companies were under obligation to split off their grids for electricity and gas from their production and supply activities before 1 January 2011 [33].

${ }^{\mathrm{c}} \mathrm{See}$ the (only in Dutch language) publication 'Eerste groen gas hub in Nederland' in the website: http:// www.energieraad.nl/newsitem.asp?pageid $=20081 \quad$ [24]. Unfortunately, the producers of biogas were not willing to sign this document. It proved impossible to find out during the interviews why they displayed this reluctance.

${ }^{\mathrm{d}}$ We take inspiration to the following from deliberations over the concept of public authority over the 1998 Human Rights Act [27].

${ }^{\mathrm{e}}$ Taken from a draft book by Heldeweg (Public governance law, an introduction to legal governance in the regulatory state, forthcoming).

${ }^{\mathrm{I}}$ In Dutch Administrative Law, the definition of 'public office' under the General Administrative Law Act (Article $1.1 \mathrm{Awb}$ ) [29] is more limited than that of
Public Authority in the UK 1998 Human Rights Act [28] and does not (yet) encompass grid operators (see the Explanatory Memorandum [34], sub 2.6, and a 2002 decision by the Administrative High Court for Trade and Industry [35]). In view of a general clause in the Civil Law code (Article 3:14 - 'Civil law powers may not be exercised in conflict with written or unwritten rules of public law') and (related) case-law, we feel that our stance (on grid operators) is radical but not out of touch with the range of applicability of general public law norms (fundamental rights, principles of natural justice, and proper government) under Dutch law.

${ }^{\mathrm{g}}$ With this contribution, we have elaborated upon our views formulated in [36] and on the governance agenda for energy transition in the Netherlands [37].

\section{Competing interests}

The authors declare that they have no competing interests.

\section{Authors' contributions}

All authors contributed to this paper. MAH, MPTS, and MH collected and sorted the sources and information material and prepared the manuscript. All authors read and approved the final manuscript.

\section{Author details}

'Department of Governance and Technology, The University of Twente, PO Box 2177500 AE, Enschede, The Netherlands. ${ }^{2}$ Saxion University of Applied Sciences, PO Box 70,000 7500 KB, Enschede, the Netherlands. ${ }^{3}$ The Netherlands Institute of Government, The University of Twente, PO Box 217 7500 AE, Enschede, The Netherlands. ${ }^{4}$ Constitutional and Administrative Law, The University of Twente, PO Box 2177500 AE, Enschede, the Netherlands.

Received: 23 June 2014 Accepted: 18 December 2014

Published online: 24 March 2015

\section{References}

1. Agentschap NL (2011) Statusdocument bio-energie 2011. Utrecht

2. Sanders MPT, Hoppe T (2013) Groengasprojecten: energietransitie in ruraal Nederland? Beleid en Maatschappij 40(2):94-117

3. Stichting Groen Gas Nederland (2011) Visie, missie \& doelen Groen Gas Nederland. Leeuwarden

4. Sanders MPT (2011) Regulating public-private modalities of legitimate innovation: an ex ante analysis framework. In: Heldeweg MA, Kica E (eds) Regulating technological innovations. An interdisciplinary approach. 152, Houndmills, pp 152-168

5. Sanders MPT, Heldeweg MA (2013) De legitimiteit van beleids- en besluitvorming in PPS bij groengasprojecten: een drievoudige casestudy. Bestuurswetenschappen 67(2):55-70

6. Rhodes RAW (1997) Understanding governance. Open University Press, Buckingham

7. Börzel TA (1998) Organizing Babylon - on the different conceptions of policy networks. Public Adm 76(2):253-273

8. Van Heffen O, Kickert WJM, Thomassen JJA (2000) Introduction: multi-level and multi-actor governance. In: Van Heffen O, Kickert WJM, Thomassen JJA (eds) Governance in modern society: effects, change and formation of government institutions. Kluwer, Dordrecht

9. Klijn EH (2008) It's the management, stupid!'. Over het belang van management bij complexe beleidsvraagstukken, Den Haag, Lemma

10. Sanders MPT, Heldeweg MA, Straatman EGP, Wempe JFDB (2014) Energy policy by beauty contests: the legitimacy of interactive sustainability policies at regional levels of the regulatory state. Energy Sustain Soc 4(4):1-13

11. Heldeweg MA, Sanders MPT (2013) Good legal governance in authoritative public-private partnerships. Conceptualising legitimate partnerships with public authority European Procurement \& Public Private Partnership Law Review 2: pp 175-185 
12. Bingham T (2010) The rule of law. Penguin, London

13. Bloomfield P (2006) The challenging business of long-term public-private partnerships: reflections on local experience. Public Adm Rev 66(3):400-411

14. Hodge GA, Greve C, Boardman AE (2010) International handbook on publicprivate partnerships. Edward Elgar, Cheltenham, UK

15. Sanders MPT (2013) Publiek-Private Samenwerking in de Nederlandse Energiesector. Vorm en legitimiteit. Den Haag, Boom Lemma

16. Sanders MPT, Heldeweg MA (2012) Publiek-private samenwerking: evenwichtskunst tussen juridisch-bestuurskundige waarden. Bestuurswetenschappen 66(1):39-56

17. Provincie F (2007) Gebiedskader Noordoost Fryslân 2007-2013. Leeuwarden

18. Landbouw Economisch Instituut (LEI) (2010) Stimuleren van concurrentie en duurzaamheid bij een nieuw Europees landbouwbeleid. Den Haag

19. voor de Leefomgeving C (2009) Nutriëntenoverschotten in de landbouw, 1970-2009. Den Haag

20. Akkerbouw P (2009) Masterplan-mineralenmanagement. Haag, Den

21. EKwadraat (2011) BioNoF, een biogasleiding met gevolgen. Leeuwarden

22. Beuningen JCBM V, Van BJ (2013) Energiewetgeving in transitie. In: Beuningen JCBM V, Van BJ, Kwast O, Noordover EMN, Van de Meester DS (eds) Complexe besluitvorming in het bestuursrecht. Boom Juridische Uitgevers, Den Haag

23. Van Economische Zaken M (2011) Landbouw \& Innovatie. Energierapport 2011, Den Haag

24. Energieraad (2010) <http://www.energieraad.nl/ newsitem.asp? pageid=20081>. Accessed 4 July 2012

25. Van Wijk HD, Konijnenbelt W, Van Male R (2011) Hoofdstukken van bestuursrecht. Reed Business, Amsterdam, p 240

26. Wetenschappelijke Raad Voor het Regeringsbeleid (WRR) (2000) Het borgen van publiek belang. Rapport aan de regering nr. 56, Den Haag, pp 20-21

27. House of Lords/House of Commons, Joint Committee on Human Rights (2003) The meaning of public authority under the Human Rights Act, seventh report of session 2003-04, HL Paper 39 HC 382

28. Human Rights Act 1998, of the 9th November 1998, 1988 c. 42

29. GALA (Awb) <http://www.cilc.nl/downloads/ General_Administrative_Law_Act.pdf>. Accessed 11 June 2014.

30. Heldeweg MA (2009) Smart Rules \& Regimes. Publiekrechtelijk(e) ontwerpen voor privatisering en technologische innovatie, Inaugural Lecture. University of Twente (with reference, in footnote 267, to authoritative policy documents on the distinction between active and passive shareholdership Enschede

31. United Nations Development Programme (2014), Governance for Sustainable Human Development: A UNDP Policy Document, <http:// mirror.undp.org/marnet/policy/chapter1.html\#b >. Accessed 23 March 2014

32. Steenhuijsen B, De Bruijne BM (2014) Reflections on the role of energy network companies in the energy transition. Conference Paper IGS-ESEIA 2014

33. Kist AW, Crone FJM, Hudig DF, Ketting NG, De Swaan T, Willems R (2008) Publiek aandeelhouderschap energiebedrijven. Ministerie van Economische Zaken, Den Haag

34. Explanatory Memorandum to Statutory Bill 33493, <https:// zoek.officielebekendmakingen.nl/kst-33493-3.html>. Accessed 13 June 2014.

35. Administrative High Court for Trade and Industry, <http://www.wetboekonline.nl/jurisprudentie/ljnAE8312.html>. Accessed 13 June 2014.

36. Sanders MPT, Heldeweg MA (2014) To PPS or not to PPS? (Publiek-)private samenwerking rond groen Gas. Bestuurswetenschappen 68(1):41-57

37. Hoppe T, Van Bueren E, Sanders MPT (2013) Naar een bestuurswetenschappelijke onderzoeksagenda voor klimaatmitigatie in Nederland en Vlaanderen. Bestuurswetenschappen 67(1):88-99

Submit your manuscript to a SpringerOpen ${ }^{\circ}$ journal and benefit from:

- Convenient online submission

- Rigorous peer review

- Immediate publication on acceptance

- Open access: articles freely available online

High visibility within the field

- Retaining the copyright to your article

Submit your next manuscript at $\gg$ springeropen.com 